\title{
Screening of some Potato Cultivars for Root- Knot Nematode (Meloidogyne javanica) and Reniform Nematode (Rotylenchulus reniformis) Infection under Greenhouse Conditions
}

\author{
Montasser S. A., A. E. Anany and A. E. Khalifa \\ Agric. Zoology and Nematology Dept.. Fac. Agric., Al-Azhar Univ. Cairo. Egypt. \\ Corresponding author email: dr.montasser.s@gmail.com
}

Received: 17 September 2018

Revised: 4 January 2019

Accepted: 8 January 2019

\begin{abstract}
Evaluation of sixteen potato (Solanum tuberosum) cultivars (Banba, Belleni, Bresius, Burren, Cara, Diamant, Hermes, Kuras, Lady Balfour, Lady Rosetta, Metro, Mondial, Solana, Synergy, Spunta and Strux) for their susceptibility and resistance against both Meloidogyne javanica and Rotylenchulus reniformis infection was tested under greenhouse conditions. The behavior of both nematode species was greatly governed by the tested cultivars. None of the potato cultivars was immune host for both nematode species infection. $M$. javanica succeeded in invading and developing on all tested potato cultivars except Kuras and Solana cvs. which were considered as highly resistant and moderately susceptible hosts, respectively. On the other hand, Belleni, Bresius, Hermes, Lady Rosetta, Solana, and Synergy were ranked as highly resistant (HR) to $R$. reniformis, while the rest cultivars showed various degrees in their susceptibility to $R$. reniformis infection.
\end{abstract}

Key words: Potato, cultivars, screening, Meloidogyne javanica, Rotylenchulus reniformis, greenhouse.

\section{INTRODUCTION}

Potatoes are a major crop in Egypt and contribute immensely to human nutrition and food security (Karim et al., 2010). Major pests of potato include various plant parasitic nematodes causing significant damage by reducing number and size of tubers that resulting in low quality of tubers. Many nematode genera especially root-knot and the reniform nematodes have been reported to attack potato in Egypt (Salem, 2006). Evaluation of potato cultivars for their susceptibility to the root-knot nematodes Meloidogyne spp. and the reniform nematode, Rotylenchulus reniformis as a promising and safe method of control has been studied by several investigators (Giffin\& Stoker,1968 ; Gonzalez \& Accatino, 1974; Robois, et al.,1978; Araujo 1982; Kheir, et al.,1982; Riveria-Smith et al.,1991 and Kandouh, 2012). Montasser, et al. (1992) examined eight potato cultivars for their relative susceptibility to the infection of each of $M$. javanica and $R$. reniformis and they reported that Alpha cv. was susceptible host to both nematode species. Also, Draga, Liest-A and Serana cvs. were susceptible hosts to $M$. javanica, but were moderately resistant, highly resistant and less susceptible 
hosts to $R$. reniformis, respectively. Giant, Kondor and Mondial cultivars were very resistant hosts to $M$. javanica whereas, were moderately resistant, less susceptible and susceptible hosts to $R$. reniformis, respectively. On the other hand, the Serana-28 cultivar was slightly resistant and highly resistant host to $M$. javanica and $R$. reniformis, respectively.

Also, Abd-Alla (1999) screened eight potato cultivars for their susceptibility against the root-knot nematodes $M$. incognita, $M$. javanica and the reniform nematode, $R$. reniformis. He found that all the tested potato cultivars were susceptible hosts against both root-knot nematode species. While, Anka, Nicola, Oliva and Yasmina and Aida, Diamont, Draga and Spunta cultivars were immune and highly resistant hosts to $R$. reniformis infection, respectively. Ibrahim, et al. (2014) tested six potato cultivars against the root-knot nematode species, M.arenaria, $M$. javanica and $M$. incognita, in the greenhouse. They found that Diamant, Lady Rosetta cvs. were highly susceptible to the tested nematode species, while Desiree, Famosa, Spunta and King Eduard cvs. were susceptible to the tested nematode. El-Sherif, et al. (2017) evaluated four potato cultivars against their suitability to $M$. incognita infection. They indicated that Cara and Draga cvs. were classified as moderately resistant hosts while Spunta and Solana cvs. were rated as highly susceptible and susceptible hosts to nematode infection, respectively.

The objective of this study was to determine the susceptibility of sixteen potato cultivars to $M$. javanica and R.reniformis under greenhouse conditions.

\section{MATERIALS AND METHODS}

One sprout of potato tuber cultivars (Banba, Belleni, Bresius, Burren, Cara, Diamant, Hermes, Kuras, Lady Balfour, Lady Rosetta, Metro, Mondial, Solana, Synergy,Spuntaand Strux) was separately planted in $20 \mathrm{~cm}$ diameter clay pots containing mixture of clay and sand soil (1:1) for two weeks. The pots were then inoculated with approximately 1000 newly hatched juveniles of Meloidogyne javanica or 1000 immature female of Rotylenchulus reniformis per plant by pipetting the nematode suspension in five holes around the root system . Each potato cultivar was replicated four times including those kept uninoculated serving as check. All pots were arranged in a randomized block design on a bench in a greenhouse. All pots were grown during the normal growing seasons at greenhouse temperature of $30 \pm 5^{\circ} \mathrm{C}$ for $M$. javanica and $20 \pm 5^{\circ} \mathrm{C}$ for $R$. reniformis after 45 days of inoculation. All plants were then harvested and removed gently washed in water then stained in lactophenol acid fuchsin (Goodey 1957). The numbers of juveniles in soil per pot, galls, developmental stages, egg masses per root were counted. Eggs of ten randomly selected egg masses of each root system was also counted. The rate of nematode reproduction was calculated. The host category of the tested potato cultivars infected with $M$. javanica based on nematode reproduction ( $\mathrm{Pf} / \mathrm{Pi})$ was determined according to Montasser, et al. (2017) as follows: (Pf / Pi = 0.0) I = Immune host; (Pf / Pi < 0.4) HR $=$ Highly resistant host; $(0.5 \leq \mathrm{Pf} / \mathrm{Pi} \leq 0.9) \mathrm{R}=$ Resistant host; $(1.0 \leq \mathrm{Pf} / \mathrm{Pi} \leq 4.9) \mathrm{LS}$ $=$ Less susceptible host; $(5.0 \leq \mathrm{Pf} / \mathrm{Pi} \leq 14.9) \mathrm{MS}=$ Moderately susceptible host and $(\mathrm{Pf} / \mathrm{Pi}>15.0) \mathrm{HS}=$ Highly susceptible host. Also, the potential of each 
cultivar to support egg production of $R$. reniformis was calculated in relation to that of Burren potato cultivar which was regarded as a check potato cultivar and host category, based on percentage of egg production of each potato cultivar was estimated according to that scale given by Montasser (1986) as follows: $0 \%=$ Immune (I), 1$10 \%=$ Highly resistant(HR), 11-20\%= Resistant (R), 21-40\%= Less susceptible (LS), $41-60 \%=$ Moderately susceptible (MS), and 61-100\%= Highly susceptible (HS). Data were subjected to analysis of variance (ANOVA) Gomez and Gomez (1984) followed by Duncan's multiple range test to compare means (Duncan, 1955).

\section{RESULTS AND DISCUSSION}

Response of sixteen potato cultivars was tested for their susceptibility to the infection with the root-knot nematode $M$. javanica under greenhouse conditions. Data presented in Table (1) and Fig.1 indicated that Kuras cv. had the lowest values of numbers of galls, juveniles in soil, nematode developmental stages, egg masses and eggs per egg mass. Also the calculated nematode final population was less than nematode inoculum population $(\mathrm{RF}=0.47)$. Significant differences $(\mathrm{p}=0.05)$ in nematode criteria on such cultivar were observed when compared with those of the other tested cultivars. On the other hand, the calculated values of nematode reproduction of the rest tested potato cultivars were ranged between 13.42 and 94.77 folds.

Plant growth response due to root knot nematode infection was determined through the estimation of the percentage reduction in plant height and fresh weights of shoots and roots (Table 2). Among the potato cultivars tested, the highest percentage reduction values of shoot length was showed in Diamant and Hermes cultivars (47.6 and $37.5 \%$ ) followed by Mondial, Cara and Burren cultivars. Meanwhile, Solana, Belleni and Synergy cultivars showed the lowest percentage reduction values (3.7, 4.2 and $8.0 \%$ ) compared to the uninoculated one, respectively. However, in the root length parameter, the highest percentage reduction values were shown in Strux and Belleni cultivars (33.0 and 30.3 \%) followed by Metro, Lady Balfour, Solana, Mondial and Kuras cultivars. While, Hermes, Cara and Lady Rosetta cultivars showed the lowest percentage reduction values (Fig. 1).

On the other hand, the highest percentage reduction values in shoot weight were recorded on Hermes, Kuras and cultivars (50.4, 50.0 and 49.0\%), respectively. Followed by Spunta and Lady Balfour cultivars, the lowest percentage reduction values included Metro and Lady Rosetta cultivars (1.3 and 1.5\%). Meanwhile, in root weight parameter, the highest percentage reduction values were shown in Belleni and Diamant cultivars (58.5 and $45.8 \%$ ), respectively, followed by Lady Rosetta and Metro cultivars. The lowest percentage reduction values were recorded on Burren and Cara cultivars (3.1 and $7.8 \%$ ), respectively (Fig. 1).

Thereupon, the tested potato cultivars were classified for their susceptibility to the root knot nematodes, $M$. javanica as follows: Kuras cultivar was highly resistant host (HR), but Solana cultivar was moderately susceptible host (MS), while other cultivars tested were found to be highly susceptible hosts (HS) (Table 1). These 
Table 1 .Susceptibility of potato cultivars as influenced by the infection of the root-knot nematode, Meloidogyne javanica under greenhouse conditions.

\begin{tabular}{|c|c|c|c|c|c|c|c|c|c|c|c|c|c|}
\hline \multirow{3}{*}{$\begin{array}{l}\text { Potato cultivars } \\
\text { Banba }\end{array}$} & \multirow{2}{*}{\multicolumn{2}{|c|}{$\begin{array}{l}\text { No.galls } \\
\text { /root }\end{array}$}} & \multicolumn{8}{|c|}{ Nematode population } & \multirow{3}{*}{$\begin{array}{c}\begin{array}{c}\text { Nematode } \\
\text { Final } \\
\text { Population } \\
(\mathrm{Pf})\end{array} \\
76819 \\
\end{array}$} & \multirow{3}{*}{$\begin{array}{c}\begin{array}{c}\text { Rate of } \\
\text { Nematode } \\
\text { reprod. } \\
*(\mathrm{RF})\end{array} \\
76.81\end{array}$} & \multirow{3}{*}{$\begin{array}{c}\begin{array}{c}\text { Host } \\
\text { Category }\end{array} \\
\text { HS } \\
\end{array}$} \\
\hline & & & \begin{tabular}{|r|} 
No. \\
juveniles in \\
soil/pot \\
\end{tabular} & \multicolumn{2}{|c|}{$\begin{array}{c}\text { Nematode } \\
\text { Develop. } \\
\text { stages/root }\end{array}$} & \multicolumn{2}{|c|}{$\begin{array}{c}\text { No.adult } \\
\text { females /root }\end{array}$} & \multicolumn{2}{|c|}{$\begin{array}{l}\text { No.egg masses } \\
\text { /root }\end{array}$} & $\begin{array}{l}\text { No. eggs/egg } \\
\text { mass }\end{array}$ & & & \\
\hline & 264 & $\mathrm{Ab}$ & $52 \mathrm{~b}$ & 8 & $\mathrm{~B}$ & 249 & $\mathrm{Ab}$ & 255 & $\mathrm{Ab}$ & 300 bcd & & & \\
\hline Belleni & 199 & Abc & $10 \quad b$ & 7 & B & 189 & Abc & 193 & Abc & 118 & 23088 & 23.08 & HS \\
\hline Bresius & 218 & $\mathrm{Abc}$ & $33 \quad b$ & 8 & $\mathrm{~B}$ & 203 & $\mathrm{Abc}$ & 211 & $\mathrm{Abc}$ & 300 bcd & 63544 & 63.54 & HS \\
\hline Burren & 293 & $\mathrm{Ab}$ & $80 \quad \mathrm{~b}$ & 133 & A & 265 & $\mathrm{Ab}$ & 285 & $\mathrm{Ab}$ & 257 cde & 73723 & 73.72 & HS \\
\hline Cara & 247 & $\mathrm{Ab}$ & $803 \quad \mathrm{a}$ & 2 & $\mathrm{~B}$ & 242 & $\mathrm{Ab}$ & 242 & $\mathrm{ab}$ & 204 defg & 50415 & 50.41 & HS \\
\hline Diamant & 276 & $\mathrm{Ab}$ & $25 \quad \mathrm{~b}$ & 2 & $\mathrm{~B}$ & 273 & $\mathrm{Ab}$ & 275 & $\mathrm{ab}$ & $316 \quad \mathrm{Bc}$ & 87200 & 87.2 & HS \\
\hline Hermes & 300 & $\mathrm{Ab}$ & $88 \quad \mathrm{~b}$ & 9 & $\mathrm{~B}$ & 270 & $\mathrm{Ab}$ & 278 & $\mathrm{ab}$ & 298 bcd & 83211 & 83.21 & $\mathrm{HS}$ \\
\hline Kuras & 10 & $\mathrm{D}$ & $75 \quad b$ & 2 & $\mathrm{~B}$ & 2 & $\mathrm{D}$ & 2 & $\mathrm{D}$ & $150 \quad \mathrm{Fg}$ & 479 & 0.47 & HR \\
\hline Lady Balfour & 182 & Abc & $183 \quad b$ & 6 & $\mathrm{~B}$ & 171 & $\mathrm{abc}$ & 177 & $\mathrm{abc}$ & 175 efg & 31335 & 31.33 & HS \\
\hline Lady Rosetta & 179 & Abc & $47 \quad b$ & 2 & $\mathrm{~B}$ & 157 & $\mathrm{Bc}$ & 158 & $\mathrm{bc}$ & 252 cde & 40022 & 40.02 & $\mathrm{HS}$ \\
\hline Metro & 264 & $\mathrm{Ab}$ & $80 \quad b$ & 2 & $\mathrm{~B}$ & 256 & $\mathrm{Ab}$ & 258 & $\mathrm{ab}$ & $366 \mathrm{Ab}$ & 94768 & 94.77 & $\mathrm{HS}$ \\
\hline Mondial & 230 & Abc & $53 \quad \mathrm{~b}$ & 7 & $\mathrm{~B}$ & 224 & $\mathrm{abc}$ & 228 & $\mathrm{abc}$ & 285 bcd & 65264 & 65.26 & $\mathrm{HS}$ \\
\hline Solana & 93 & $\mathrm{Cd}$ & $133 \quad b$ & 8 & $\mathrm{~B}$ & 78 & $\mathrm{Cd}$ & 82 & $\mathrm{~cd}$ & $161 \mathrm{efg}$ & 13421 & 13.42 & MS \\
\hline Synergy & 311 & $\mathrm{Ab}$ & $108 \quad b$ & 11 & $\mathrm{~B}$ & 289 & $\mathrm{Ab}$ & 300 & $\mathrm{ab}$ & 235 cdef & 70908 & 70.91 & $\mathrm{HS}$ \\
\hline Spunta & 333 & $\mathrm{~A}$ & $23 \quad b$ & 5 & $\mathrm{~B}$ & 327 & $\mathrm{~A}$ & 332 & A & 220 cdef & 76715 & 76.72 & $\mathrm{HS}$ \\
\hline Strux & 158 & $\mathrm{Bc}$ & $160 \quad b$ & 5 & $\mathrm{~B}$ & 151 & $\mathrm{Bc}$ & 156 & & $449 \quad \mathrm{a}$ & 70360 & 70.36 & $\mathrm{HS}$ \\
\hline
\end{tabular}

Means in each column followed by the same letter(s) are not significantly different by $(\mathrm{P}=0.05)$ according to Duncan's multiple range test; *Rate of nematode reproduction $(\mathrm{RF})=\mathrm{Pf} / \mathrm{Pi}$; Final population, Initial population. 


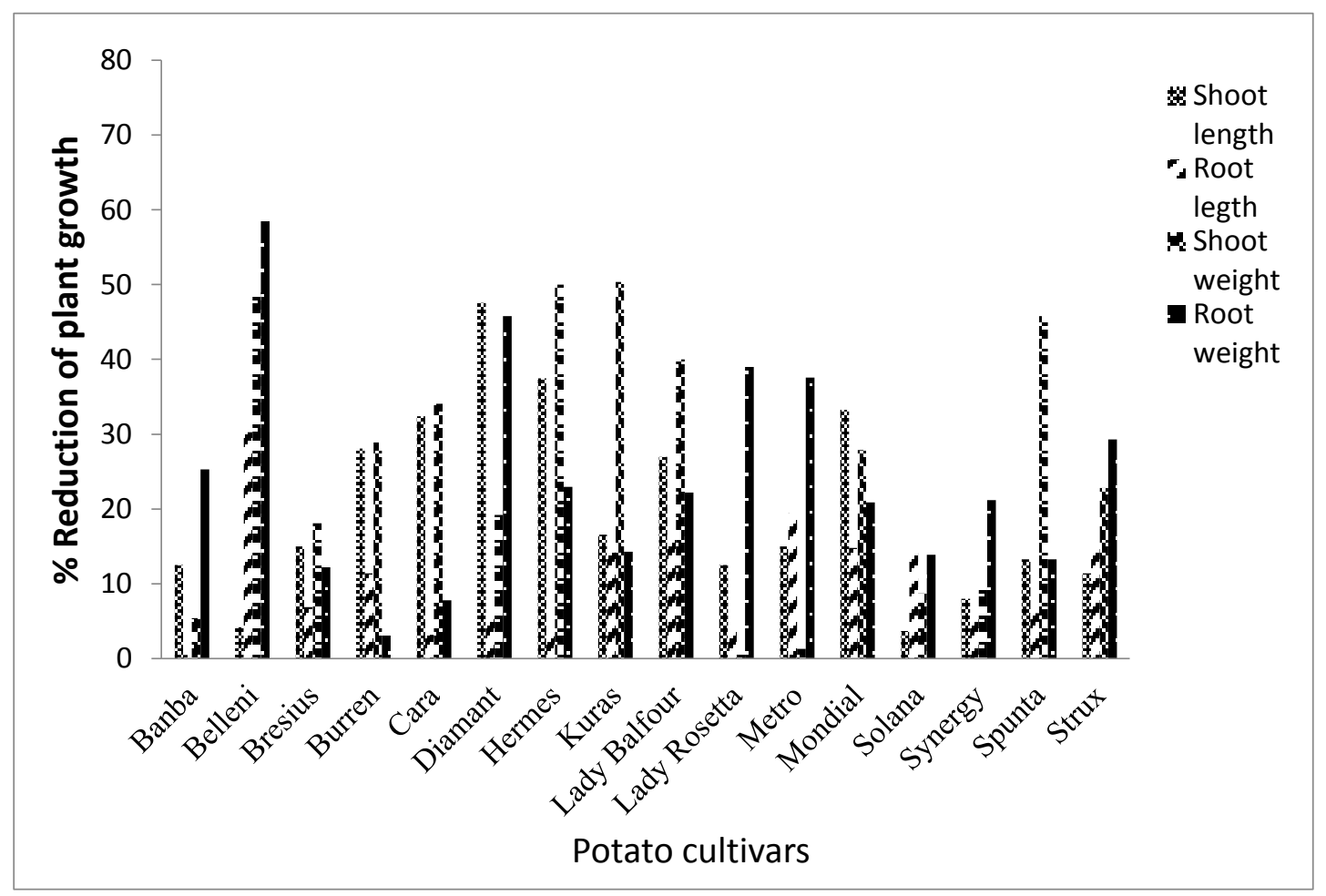

Fig 1. Plant growth parameters of potato cultivars as influenced with the infection of the rootknot nematode Meloidogyne javanica under greenhouse conditions.

results are in agreement with Montasser et al. (1992) and Bekhiet et al. (2010). AbdElgawad et al. (2012) indicated that Spunta and Diamant potato cultivars were susceptible to $M$. incognita infection. Youssef, (2013) who recognized root-knot nematodes as one of the major parasites of potato, found that losses vary depending upon the cultivar. Also, previous studies by Vovlas et al. (2005) reported a typical susceptible reaction of potato cultivars Cara and Spunta to infection by M. javanica.

The sixteen potato cultivars were also tested for their resistance to R.reniformis infection under greenhouse conditions. Data in Table (2) suggested that R.reniformis failed to develop and reproduce on Belleni, Bresius, Hermes, Lady Rosetta, Solana and Synergy cultivars resulting the lowest values of nematode reproduction and percentage of egg production which ranged between $0.26 \& 1.06$ folds and $2.57-$ 7.78, respectively. On Diamant, Kuras, Metro and Spunta cultivars, the reniform nematode reproduced moderately yielding the moderate values of nematode reproduction $(2.36,2.18,1.62 \& 2.65$ folds) and percentage of egg production (18.82, $17.32,11.09 \& 18.99 \%$ ), respectively. One the other hand, the rest potato cultivars gave the highest values of nematode reproduction and percentage of egg production which ranged between 3.18 and 12.66 folds and 24.19 and $100 \%$, respectively (Fig. 2). Plant growth response due to reniform nematode infection was determined through the 
Table 2. Susceptibility of potato cultivars as influenced with the infection of the reniform nematode, Rotylenchulus reniformis under greenhouse conditions.

\begin{tabular}{|c|c|c|c|c|c|c|c|c|c|c|c|c|c|c|}
\hline \multirow{3}{*}{$\begin{array}{l}\text { Potato cultivars } \\
\text { Banba }\end{array}$} & \multicolumn{10}{|c|}{ Nematode population } & \multirow{3}{*}{$\begin{array}{c}\begin{array}{c}\text { Nematode } \\
\text { Final } \\
\text { Population } \\
(\mathrm{Pf})\end{array} \\
6243\end{array}$} & \multirow{3}{*}{$\begin{array}{c}\begin{array}{c}\text { Rate of } \\
\text { Nematode } \\
\text { reprod. } \\
*(\mathrm{RF})\end{array} \\
6.24\end{array}$} & \multirow{3}{*}{$\begin{array}{l}\text { **Egg } \\
\text { Prod. } \\
\% \\
51.15\end{array}$} & \multirow{3}{*}{$\begin{array}{c}\begin{array}{c}\text { Host } \\
\text { Category }\end{array} \\
\mathrm{MS}\end{array}$} \\
\hline & \multicolumn{2}{|c|}{$\begin{array}{r}\text { No. juveniles } \\
\text { in soil/pot }\end{array}$} & \multicolumn{2}{|c|}{$\begin{array}{c}\text { Nematode } \\
\text { Develop. } \\
\text { stages/root }\end{array}$} & \multicolumn{2}{|c|}{$\begin{array}{c}\text { No.adult } \\
\text { females /root }\end{array}$} & \multicolumn{2}{|c|}{$\begin{array}{c}\text { No.egg masses } \\
\text { /root }\end{array}$} & \multicolumn{2}{|c|}{$\begin{array}{l}\text { No. eggs/egg } \\
\text { mass }\end{array}$} & & & & \\
\hline & 116 & $\mathrm{~F}$ & 20 & ef & 113 & $\mathrm{D}$ & 111 & $\mathrm{E}$ & 54 & $\mathrm{~cd}$ & & & & \\
\hline Belleni & 190 & $\mathrm{E}$ & 1 & $\mathrm{i}$ & 10 & I & 6 & $\mathbf{J}$ & 70 & $\mathrm{a}$ & 621 & 0.26 & 3.58 & HR \\
\hline Bresius & 80 & $\mathrm{~F}$ & 5 & hi & 8 & I & 7 & $\mathbf{J}$ & 43 & $\mathrm{e}$ & 394 & 0.39 & 2.57 & HR \\
\hline Burren & 600 & $\mathrm{a}$ & 112 & $\mathrm{a}$ & 223 & $\mathrm{~A}$ & 217 & $\mathrm{~A}$ & 54 & $\mathrm{~cd}$ & 12653 & 12.66 & 100.0 & HS \\
\hline Cara & 389 & $\mathrm{~b}$ & 66 & $\mathrm{~b}$ & 141 & $\mathrm{C}$ & 130 & $\mathrm{D}$ & 39 & ef & 5744 & 5.74 & 43.93 & MS \\
\hline Diamant & 90 & $\mathrm{f}$ & 22 & ef & 38 & $\mathrm{~F}$ & 35 & $\mathrm{G}$ & 63 & $\mathrm{~d}$ & 2355 & 2.36 & 18.82 & $\mathrm{R}$ \\
\hline Hermes & 70 & $\mathrm{f}$ & 6 & hi & 9 & I & 9 & $\mathrm{~J}$ & 55 & $\mathrm{~cd}$ & 580 & 0.58 & 4.22 & HR \\
\hline Kuras & 102 & $\mathrm{f}$ & 8 & $\mathrm{gh}$ & 35 & $\mathrm{~F}$ & 35 & $\mathrm{G}$ & 58 & bc & 2178 & 2.18 & 17.32 & $\mathrm{R}$ \\
\hline Lady Balfour & 350 & $\mathrm{~b}$ & 55 & $\mathrm{c}$ & 144 & $\mathrm{C}$ & 140 & $\mathrm{C}$ & 76 & $\mathrm{a}$ & 11189 & 11.19 & 90.80 & HS \\
\hline Lady Rosetta & 70 & $\mathrm{f}$ & 3 & hi & 19 & $\mathrm{H}$ & 18 & I & 37 & ef & 757 & 0.75 & 5.68 & HR \\
\hline Metro & 275 & $\mathrm{~cd}$ & 13 & $\mathrm{~g}$ & 28 & $\mathrm{G}$ & 26 & $\mathrm{H}$ & 50 & $\mathrm{~d}$ & 1616 & 1.62 & 11.09 & $\mathrm{R}$ \\
\hline Mondial & 590 & $\mathrm{a}$ & 40 & $\mathrm{~d}$ & 210 & $\mathrm{~B}$ & 165 & $\mathrm{~B}$ & 33 & fg & 6285 & 6.29 & 46.46 & MS \\
\hline Solana & 90 & $\mathrm{f}$ & 39 & $\mathrm{~d}$ & 27 & $\mathrm{G}$ & 24 & $\mathrm{Hi}$ & 38 & ef & 1068 & 1.06 & 7.78 & HR \\
\hline Synergy & 213 & de & 3 & hi & 11 & I & 10 & $\mathrm{~J}$ & 52 & $\mathrm{~cd}$ & 746 & 0.75 & 4.44 & HR \\
\hline Spunta & 325 & $\mathrm{bc}$ & 25 & $\mathrm{e}$ & 78 & $\mathrm{E}$ & 89 & $\mathrm{~F}$ & 25 & $\mathrm{~h}$ & 2653 & 2.65 & 18.99 & $\mathrm{R}$ \\
\hline Strux & 214 & de & 19 & $\mathrm{f}$ & 115 & $\mathrm{D}$ & 105 & $\mathrm{E}$ & 27 & $\mathrm{gh}$ & 3183 & 3.18 & 24.19 & LS \\
\hline
\end{tabular}

Means in each column followed by the same letters are not significantly different by $(\mathrm{P}=0.05)$ according to Duncan's multiple range test; $*$ Rate of nematode reproduction $(\mathrm{RF})=$ Pf / Pi; Final population, Initial population ; $\quad * * E g g$ production $\%=\frac{\text { Egg masses } \times \text { eggs,test cultivar }}{\text { Egg masses } \times \text { eggs,Burren cultivar }} \times 100$ 


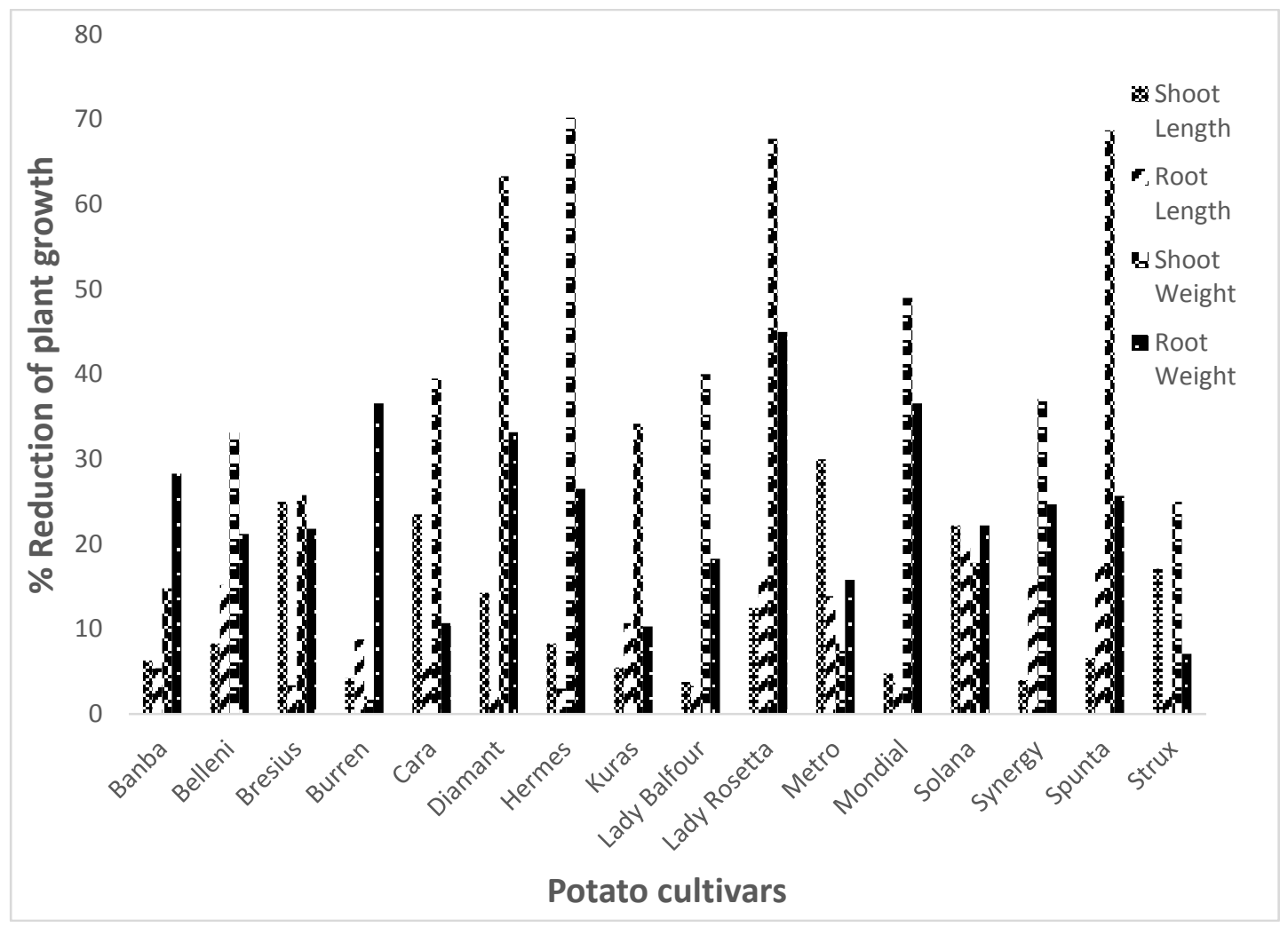

Fig 2. Plant growth parameters of potato cultivars as influenced with the infection of the reniform nematode, Rotylenchulus reniformis under greenhouse condition.

estimation of the percentage reduction in plant height and dry weights of shoots and roots (Fig. 2). Among the potato cultivars tested, the highest percentage reduction values of shoot length were shown in Metro cultivar (30.0\%) followed by Bresius, Cara and Solana cultivars (25.0, 23.5 and $22.2 \%$, respectively). Meanwhile, Lady Balfour, Synergy, Burren and Mondial cultivars showed the lowest percentage reduction values $(3.8,4.0,4.2$ and $4.8 \%)$ compared to the uninoculated one respectively. However, in the root length parameter, the highest percentage reduction values were shown in Solana $(20.0 \%)$ and Spunta $(18.2 \%)$ cultivars followed by Lady Rosetta and Belleni cultivars. while, Diamant, Hermes, Strux, Lady Balfour and Mondial cultivars showed the lowest percentage reduction values. Also, the highest percentage reduction values in shoot weight were recorded on Hermes, Spunta, Lady Rosetta and Diamant cultivars (70.2, 68.7, 67.7 and $63.3 \%)$, respectively. The lowest percentage reduction values included Burren(2.1\%) and Metro (8.3\%) cultivars. Meanwhile, in root weight parameter, the highest percentage reduction values were shown in Lady Rosetta, Burren and Mondial cultivars (45.0, 36.6 and $36.6 \%$ ), respectively, followed by Diamant and Banba cultivars. The lowest percentage reduction values were indicated in Strux, Kuras and Cara cultivars (7.1, 10.3 and $10.7 \%$ ), respectively (Fig.2). 
Based on Burren cultivar used as a comparable plant to assess the response of the tested potato cultivars for $R$. reniformis infection, the cultivars Belleni, Bresius, Hermes, Lady Rosetta, Solana and Synergy could be classified as highly resistant hosts (HR), while Diamant, Kuras, Metro and Spunta cvs. were resistant hosts (R) to the reniform nematode infection. The rest tested potato cultivars were ranked as less moderate or highly susceptible hosts (Table 2). These results support the findings of Montasser et al. (1992) and Bekhiet et al. (2010). Alpha and Mondial cultivars were susceptible hosts to $R$. reniformis nematode, while Serana and Kondor were less susceptible hosts.

In conclusion, the present study declared that Kuras was the only potato cultivar that resist $M$. javanica and ten cultivars were classified as resistant and highly resistant to $R$. reniformis, a promising result that could be recommended to be used within integrated pest management after further studies under greenhouse and field conditions.

\section{REFERENCES}

Abd-Alla, M. B. (1999). Ecological and biological studies on nematodes and other pests associated with certain vegetable crops . Ph. D Thesis Agric. Al-Azhar Univ. Cairo, Egypt. 165 pp .

Abd-Elgawad, M. M. M.; Marie-Clair, K.;Sergio-Molinari; Abd-El-Kareem, F.; Kabeil-Sanaa, S. A.; Moawad, M. M. and El-Nagdi-Wafaa, A.(2012). Histopathological changes and enzymatic activities induced by Meloidogyne incognitaon resistant and susceptible potato.Sci J. Plant Pathol. 1: 62-72 .

Araujo, M. T. (1982). Breeding vegetable crops for resistance to root-knot

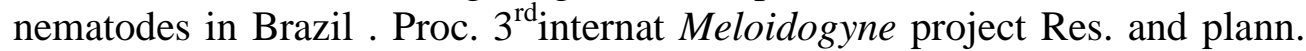
Conf. on root-knot nematodes Meloidogyne spp. Region III pp. 60 .

Bekhiet,M.A.; Kella,A.M; Khalil,A.E. and Tohamy, A.A.(2010).Interaction between root-knot nematode, Meloidogyne incognita and the bacterium, Ralstoniasolanacearumon potato. Plant Protect.Patho.J,.1(7): 505 - 518.

Duncan, D. B. (1955). Multiple range and multiple F. test Biometries 11, 1-42 .

El-Sherif, A. G.; Abdel-Hady A.A.; Gad, S.B.and Hefny, M. M.(2017). Host suitability of four potato cultivars to Meloidogyne incognita infection under greenhouse conditions.Egypt. J. Agronematol. 16(1): 30-38

Griffin,G. D. and Stoker,G. L. (1968). Susceptibility of eighteen potato varieties to Meloidogyne hapla. Plant Dis. Reptr. 52: 956 - 957.

Gomez,K. A. and Gomez, A. A. (1984). Statistical procedures for agricultural Research . $2^{\text {nd }}$ Ed., John Wiley \&Sons : Inc., New York .

Gonzalez, R. H. and Accatino, L. P. (1974). Reaction of different potato varieties to Meloidogyne incognita acrita. Agric. Technic 34: 177- 181 .

Goodey, L. B. (1957). Laboratory methods for work with plant and soil nematodes. Bull. No. 2, Min. Agric. Fish and Food, London 47 pp.

Ibrahim, I. K. A.; Mokbol-Asmaa, A. and Hammad-Sandy, E. (2014). Host suitability of some solanaceous plant cultivars to the root-knot nematodes Meloidogyne sp. Res. J. Agric. Sci. 3(5) : 136-140 
Kandouh,B.H. (2012). Susceptibility and tolerance of red skinned potato (Solanum tuberosum L.) to root-knot nematode, Meloidogyne spp. M.Sc.thesis Univ.Hawaii USA.54 pp.

Karim. M.R.; Hanif,M.M.; Shahidullah,S.M.; Rahman,A.H.M.A.; Akanda, A.M. and Khair, A. M. (2010).Virus free seed potato production through sprout cutting technique under net-house. African J. Biotech. 9: 5852-5858.

Kheir, A. M.;Abdel-Bari, N. A. and Abadir, S. K. (1982). Parasitism of certain potato cultivars by Meloidogyne incognita and Rotylenchulus reniformis .Res. Bull. Fax. Agric. Zagazig 5: 1-11.

Montasser,S. A.(1986). Resistance in tomato cultivars to the reniform nematode, Rotylenchulus reniformis. Pak. J. Nematol. 4 (2) : 79-82 .

Montasser, S. A.; Al-Sayed, A. A. and Ahmed, S. S. (1992). Varietal response of potato to Meloidogyne javanica and Rotylenchulus reniformis . Ann. Agric. Sci. Moshtohor 30: 607-613 .

Montasser,S.A.;Mahmoud, N. A.; El-Mesalamy, A. F. and Abdel-Mageed, M. A. A. (2017). Evaluation of six leguminous crops against the root-knot nematode Meloidogyne javanica infection. Pak. J. Nematol. 35 (1) : 79-84.

Robbis, R. V. ;Eldridgy, B. J. and Webb, R. E. (1978). Rotylenchulus reniformis parasitism of potatoes and its effect on yields. Plant Dis. Reptr. 62: 520 -523.

Rivera-Smith, G. E.; Ferris, H. and Voss, R. E. (1991). The application of an excised root assay for the determination of susceptibility of resistance to root-knot nematodes (Meloidogyne spp. Goeldi) in potatoes (Solanum spp. L) American Potato J. 68: 133-142.

Salem, M. M. H. (2006). Studies on root-knot nematode Meloidogyne spp. parasitizing certain solanaceae plants with reference to biological control. M.Sc.Thesis.Fac. Agric..Mans Univ. 152pp.

Vovlas, N.; Mifsud, D. ;Landa, B. B. and Castillo, P. (2005). Pathogenicity of the root-knot nematode Meloidogyne javanica on potato . Plant Pathol. 54 : 657664.

Youssef, M.M.A. (2013). Potato nematodes and their control measures: a review. Arch. Phytopathol. Plant Protect. 46(11):1371-1375. 


\section{الملخص العربى}

\section{إختبار حساسية بعض أصناف البطاطس للإصابة بكل من نيماتودا تعقد الجذور والنيماتودا الكلوية تحت ظروف الصوية}

\section{سبد عبد العزيز منتصر - عبدالمنعم السعيد عنانى - أحمد عيد خليفة \\ قسم الحيوان الزراعى وإلنيماتودا - كلية الزراعة - جامعة الازهر بالقاهرة}

تم اختبار حساسية ستة عثر صنف من البطاطس المستوردة تبعا لدرجة استجابتها للاصابة بنيماتودا تعقد الجذور والنيماتودا الكلوية وذلك تحت ظروف الصوبة وقد أظهرت جميع الاصناف المختبرة تباينا كبيرا فى درجة استجابتها للاصابة بالنيماتودا وفقا لاختلاف صنف العائل ونوع النيماتودا ـ وقد تم قياس مدى الحساسية للاصابة على اساس معدل تكاثز نيماتودا تعقد الجذور والتى اشارت الى ان صنف كوراز أظهر درجة عالية من المقاومة بينما الصنف سولانا اظهر درجة متوسطة من المقاومة بينماصنفت باقى الاصناف الاخرى المختبرة كعوائل عالية الحساسية للاصابة بنيماتودا تعقد الجذور وعلى الصعيد الاخر تم قياس مدى حساسية الاصناف للاصابة بالنيماتودا الكلوية على اساس قياس النسبة المئوية لمعدل انتاج البيض والتى اثنارت الى لى ان الاصناف بيللينى ، بريسيس ، هرمس ، ليدى روزيتا ، سولانا ، سينارجى اظهرت درجة عالية من المقاومة

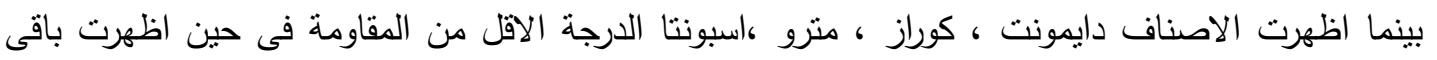
الاصناف درجات مختلفة من الحساسية للاصابة بالنيماتودا الكلوية . 